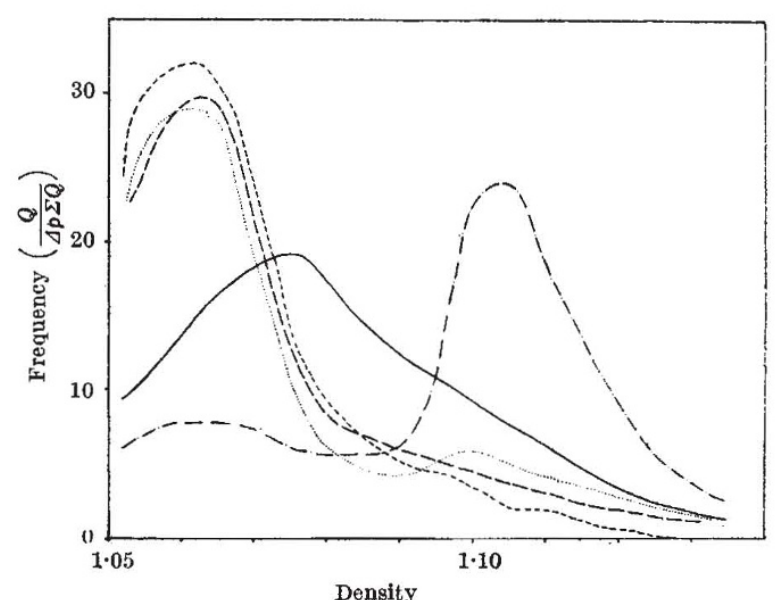

Fig. 3. Distribution of reference enzymes, proteins and radioactivity. Experimental conditions were as in Fig. 1. The mitochondrial prepara tion comes from a rat injected with $4 \mathrm{~g}$ of sucrose dissolved in $8 \mathrm{ml}$. of distilled water to which was added $20 \mu \mathrm{c}$. of sucrose labelled with carbon-14, and killed $2 \mathrm{~h}$ after the injection. Radioactivity was measured in a liquid scintillation system using an Ekco scintillator. -...--, acid phosphatase ; - - - , acid ribonuclease; ...., radioactivity; -...-, proteins; - catalase

Further, taken together with the morphological observations of Brewer and Heath ${ }^{5}$, our observations on the consequences of a hypertonic sucrose injection in the rat strongly support the hypothesis that vacuolation of the liver cell, produced by this treatment, is initiated by an accumulation of sucrose in the lysosomes.

This work was supported by a grant from the Fonds National de la Recherche Scientifique.

$$
\begin{aligned}
& \text { R. Wattraux } \\
& \text { S. Wattraux-DE Contnck } \\
& \text { M-J. RutGents } \\
& \text { P. TuLKENS }
\end{aligned}
$$

Laboratory of Physiological Chemistry,

Universitaires Faculté Notre-Dame de la Paix, Namur, Belgium.

${ }^{1}$ Beaufay, H., Bendall, D. S., Baudhuin, P., Wattiaux, R., and de Duve, C., Biochem. J., 73, 628 (1959).

${ }^{2}$ de Duve, C., Pressman, B. C., Gianetto, R., Wattiaux, R., and Appelmans, F., Biochem, J., 60, 604 (1955).

'Wattiaux, R., Wibo, M., and Baudhuin, P., Ciba Found. Symp. Lysosomes, 176 (J. and A. Churchill, Ltd., London, 1963).

- Wattiaux, R., Rutgeerts, M. J., and Wattiaux-de Coninck, S., Sixth Intern. Congr. Biochem., Abst. 669'(1964).

${ }^{5}$ Brewer, D. B., and Heath, D., Nature, 198, 1015 (1963).

- Beaufay, H., Jacques, P., Baudhuin, P., Sellinger, O. Z., Berthet, J., and de Duve, C., Biochem. J. (in the press).

'Baudhuin, P., Beaufay, H., Rahman-Li, Y., Sellinger, O. Z., Wattiaux, R., Jacques, P., and de Duve, C., Biochem. J. (in the press).

${ }^{8}$ Lowry, O. H., Rosebrough, N. J., Farr, A. L., and Randall, R. J., J. Biol. Chem., 183, 265 (1951).

\section{Effect of Glucose on Insulin Secretion in vitro by Rabbit Pancreas pre-incubated with $\beta$-Hydroxybutyrate}

WE have shown ${ }^{1}$ that $\beta$-hydroxybutyrate does not induce secretion of insulin in vitro as does glucose or citrate. Newsholme, Randle and Manchester ${ }^{2}$ have observed a diminution of uptake of glucose (perfused heart) in the presence of $\beta$-hydroxybutyrate, acetoacetate and octonoate. They conclude that these substrates inhibit uptake of glucose by inhibiting the intracellular phosphorylation of glucose by hexokinase and the phosphofruetokinase reaction. According to Passonneau and Lowry ${ }^{3}$ phosphofructokinase is responsive to the balance between $\sim \mathrm{P}$ expenditure and $\sim \mathrm{P}$ formation. In view of those results we decided to ascertain the effect of glucose on insulin secretion in vitro by rabbit pancreas pre-treated with $\beta$-hydroxybutyrate.

A piece of rabbit pancreas weighing $250 \mathrm{mg}$ was incubated in Krebs-Henseleit buffer containing $\beta$-hydroxy-

butyrate $1 \times 10^{-12} \mathrm{M}$ plus glucose $0.6 \mathrm{mg} / \mathrm{ml}$. and another piece of the same weight $( \pm 1 \mathrm{mg})$ was incubated in the same buffer containing glucose $0.6 \mathrm{mg} / \mathrm{ml}$. for $30 \mathrm{~min}$ at $37^{\circ} \mathrm{C}$. After washing, the pieces of pancreas were incubated for $15 \mathrm{~min}$ in buffer containing $3 \mathrm{mg} / \mathrm{ml}$. glucose. Extraction of insulin from the buffer was performed according to the method of Grodsky and Tarver and estimated by the technique of epididymal fat tissue ${ }^{4}$. The effect of insulin was expressed as uptake of glucose and the statistical analysis of the results was performed using the paired observations method $^{5}$.

Table 1. EFFeCT OF GLUCOSE (3 MG/ML.) on INSULIN SECRETION in vitro BY RABBIT PANCREAS PRE-INCUBATED WITH $\beta$-HYDROXYBUTYRATE $\left(1 \times 10^{-3} \mathrm{M}\right)$

$$
\begin{array}{lc}
\multicolumn{1}{c}{\text { Metabolites }} & \begin{array}{c}
\text { Mean glucose uptake } \\
(\mathrm{mg} / 100 \mathrm{mg} \text { tissue } / 4 \mathrm{~h})
\end{array} \\
\beta \text {-Hydroxybutyrate } & \\
\begin{array}{l}
\text { +glucose (25) } \\
\text { Glucose (25) }
\end{array} & 0.352 \\
\hline
\end{array}
$$

* S.E.M, the numbers in brackets give the number of experiments.

As can be seen from Table 1, the insulin extracted from the incubation buffer, in which was a piece of pancreas pre-incubated with $\beta$-hydroxybutyrate, is significantly less than the control. The effect of glucose as stimulus for insulin secretion in vitro seems to be reduced by pretreatment with this ketone body.

We thank Dr. S. Ochoa for his advice. This work was supported in part by a grant from Eli Lilly Co.

$$
\begin{aligned}
& \text { J. RoJas } \\
& \text { P. Meneses } \\
& \text { J. L. R-CANDELA }
\end{aligned}
$$

Instituto 'G. Marañon'

$$
\text { Velazquez } 138
$$

Madrid 6.

${ }^{2}$ Candela, J. L. R-, Candela, R. R-., and Martin-Hernandez, D., Nature, 195, 711 (1962).

${ }^{2}$ Newsholme, E. A., Randle, P. J., and Manchester, K. L., Nature, 193, 270 (1962). 3 Passonneau, J. V., and Lowry, O. H., Biochem. Biophys. Res. Commun., 13,
372 (1963).

4 Grodsky, G., and Tarver, H., Nature, 177, 223 (1956).

${ }^{5}$ de la Loma, J. L., Experimentación Agricola, Hispano-American Edition (Mexico).

\section{Co-precipitating Properties of 3 S Fragments derived from Horse Antitoxins}

Nisonofr et al. ${ }^{1,2}$ showed that precipitating fragments of rabbit antibody obtained by peptic digestion (5 $S$ fragments) could be transformed by reductive cleavage into non-precipitating univalent $3 S$ fragments. These results have been taken into account for the new scheme developed by Porter ${ }^{3}$ for rabbit $\gamma$-globulin structure.

We prepared $5 S$ fragments by peptic digestion ${ }^{4-6}$ of specific precipitate (diphtheria toxin $+\beta-2$-type horse antitoxin) using $0.08 \mu \mathrm{g}$ of erystallized pepsin $(p \mathrm{H}=2 \cdot 8$; $0.066 \mathrm{M}$ phosphate buffer, $30 \mathrm{~min} ; 20^{\circ} \mathrm{C}$ ). After neutralization and equilibration with 0.02 phosphate buffer $p \mathrm{H}=7.8$ containing $0.011 \mathrm{M}$ sodium chloride, the soluble fraction is passed through a DEAE-cellulose column. The first part of the non-adsorbed fraction is collected: it is 70-90 per cent precipitable by antigen (diphtheria toxin 3. 100 Lf units*/mg nitrogen) and has a sedimenta tion constant of about $5 S$. It will be abbreviated here as $P$ (precipitating $5 S$ fragment). Reduction of $P$ is not so easy as the reduction of rabbit $5 S$ fragment ${ }^{1}$. Tho reduction is performed with $0 \cdot 100 \beta$-mercaptoethanol for $18 \mathrm{~h}$ at $20^{\circ} \mathrm{C}$ and $p \mathrm{H}=7 \cdot 5$. After alkylation (with $0 \cdot 125 \mathrm{M}$ monoiodacetamide) and dialysis, we obtain a fragment having a sedimentation constant equal to $3.0 \mathrm{~S}$ (value extrapolated to zero concentration of protein). It can be kept at $-15^{\circ} \mathrm{C}$ without alteration: the product does not aggregate or precipitate spontaneously.

The neutralizing activity is retained, being equal to 80-90 per cent of the activity of $P$, without change of dilution ratio as expressed in Cinader's notation ${ }^{6}$. The

* Flocculation units. 